\title{
Hubungan Jumlah Pemberian Hijauan dan Jumlah Pemberian Air Minum Terhadap Umur Pertama Beranak Sapi PO
}

\author{
Relationship Between The Amount Of Forage And The Amount Of Drinking Water For The \\ First Calving Age for PO Cattle
}

\author{
Kunaifi Wicaksana ${ }^{1}$ dan Dani Nur Arifin ${ }^{2}$ \\ ${ }^{1}$ Program Studi Peternakan Fakultas Peternakan Universitas Tulang Bawang Lampung \\ Jl. Gajah Mada. No. 34 Kota Baru, Bandar Lampung 35121 \\ Corresponding e-mail: kunaifi.wicaksana@gmail.com
}

\begin{abstract}
This study aims to analyze the relationship between the amount of forage and the amount of drinking water given to the age at first birth so that it can be used as material for improvement in management of PO cattle breeding. The research method was in the form of a survey, the data variables were the amount of forage, the amount of drinking water, and the first calving age and the data analysis was descriptive, regression and correlation. The results of the study, the first calving age $3.36 \pm 0.50$ years was classified as slower. The amount of forage and the amount of drinking water had a very significant effect and was negatively associated with the calving first age. The closeness level of the amount of forage and the amount of drinking water given to the age at first birth was classified as moderate. Based on the results of the study, it can be concluded that, the first calving age is $3.36 \pm 0.50$. The amount of forage and the amount of drinking water had a very significant effect and was negatively associated with the first calving age. The level of relationship between the amount of forage and the amount of drinking water for the first calving age is moderate.
\end{abstract}

Key words: The amount of drinking water, the amount of forage, the first calving age, PO cattle.

\begin{abstract}
ABSTRAK
Penelitian ini bertujuan untuk menganalisis hubungan jumlah pemberian hijauan dan jumlah pemberian air minum terhadap umur pertama beranak sehingga dapat menjadi bahan perbaikan manajemen pembibitan sapi PO. Metode penelitian berupa survei, variabel data berupa jumlah pemberian hijauan, jumlah pemberian air minum, dan umur pertama beranak dan analisis data berupa deskriptif, regresi, dan korelasi. Hasil penelitian umur pertama beranak adalah 3,36 $\pm 0,50$ tahun tergolong lebih lambat. Jumlah pemberian hijauan dan jumlah pemberian air minum berpengaruh sangat signifikan dan berasosiasi negatif terhadap umur pertama beranak. Tingkat keeratan jumlah pemberian hijauan dan jumlah pemberian air minum terhadap umur pertama beranak tergolong sedang. Berdasarkan hasil penelitian dapat ditarik kesimpulan diantaranya umur pertama beranak adalah $3,36 \pm 0,50$. Jumlah pemberian hijauan dan jumlah pemberian air minum berpengaruh sangat signifikan serta berasosiasi negatif terhadap umur pertama beranak. Tingkat keeratan jumlah pemberian hijauan dan jumlah pemberian air minum terhadap umur pertama beranak tergolong sedang.
\end{abstract}

Kata kunci: Jumlah pemberian air minum, jumlah pemberian hijauan, umur pertama beranak, Sapi PO

\section{PENDAHULUAN}

Kecamatan Tanjung Sari selama ini dikenal sebagai kawasan pembibitan dan produksi sapi lokal varietas peranakan ongole atau PO, populasi sapi di kawasan ini sebanyak lima ribuan ekor dengan jumlah peternak sebanyak 40-an kelompok. Pencanangan Kecamatan Tanjung Sari sebagai kawasan sentra peternakan rakyat merupakan salah satu upaya Lampung untuk mendukung program swasembada daging nasional dan meningkatkan produktivitas ternak (sapi 
PO) (Lampungprov.go.id).

Pembibitan sapi PO membutuhkan waktu yang lebih lama dalam pemeliharaan dan keuntungan yang tipis dibanding penggemukan. Selain daripada itu pembibitan memiliki kompleksitas yang lebih dibandingkan dengan penggemukan dalam hal pemeliharaan, sehingga membutuhkan penanganan yang lebih ekstra dari peternak agar produktivitas ternak dapat optimal.

Salah satu parameter produktivitas ternak yang penting adalah umur pertama beranak. Umur pertama beranak merupakan saat dimana sapi mengalami beranak untuk pertama kalinya. Umur pertama beranak adalah faktor luar yang mempengaruhi produsksi susu. Sapi-sapi yang beranak pada umur tiga tahun akan menghasilkan susu lebih banyak daripada sapi yang beranak pada umur dua tahun karena sapi pada umur dua tahun masih mengalami pertumbuhan sehingga sapi umur tiga tahun lebih besar tubuhnya (Pirlo et al, 2000). Adapun yang dapat memengaruhi umur pertama beranak diantaranya jumlah hijauan yang diberikan dan jumlah pemberian air minum.

Dari uraian diatas peneliti merasa perlu untuk menganalisis hubungan jumlah pemberian hijauan dan jumlah pemberian air minum terhadap umur pertama beranak sehingga dapat menjadi bahan perbaikan manajemen pembibitan sapi PO.

\section{METODELOGI}

\section{Metode Penelitian}

Penelitian dilakukan di Desa Purwodadi Kecamatan Tanjung Sari, Kabupaten Lampung Selatan pada Maret - April 2020. Data yang digunakan dalam penelitian ini berupa data sekunder meliputi data jumlah pemberian hijauan, jumlah pemberian air minum, dan umur pertama beranak dengan jumlah sapi PO sebanyak 55 ekor dari 34 peternak.

\section{Analisis Data}

Data sekunder ditabulasikan menggunakan Microsoft Excel 2013 sedangkan analisis data menggunakan aplikasi Minitab 2016. Analisis data yang dilakukan antara lain analisis deskriptif untuk mendeskripsikan hasil penelitian kedalam pembahasan (Walpole, 1992), analsisis regresi linier untuk mengetahui bentuk hubungan antar variabel (Steel dan Torrie, 1997), dan analisis korelasi untuk mengetahui keeratan hubungan antar variabel (Walpole, 1992). Adapun interpretasi korelasi dapat dilihat pada Tabel 1.

2 Hubungan Jumlah Pemberian Hijauan dan Jumlah ... 
Tabel 1. Interpretasi korelasi

\begin{tabular}{cl}
\hline \multicolumn{1}{c}{ Besar xy } & Interpretasi \\
\hline $0.00-<0.20$ & Hubungan antar variabel sangat rendah \\
$0.00-<0.20$ & Hubungan antar variabel sangat rendah \\
$\geq 0.20-<0.40$ & Hubungan antar variabel rendah \\
$\geq 0.40-<0.70$ & Hubungan antar variabel sedang/ cukup \\
$\geq 0.70-<0.90$ & Hubungan antar variabel kuat/ tinggi \\
$\geq 0.90-\leq 1.00$ & Hubungan antar variabel sangat kuat/ tinggi
\end{tabular}

Sumber: Guilford (1956), diacu dalam Somantri dan Sambas (2006).

\section{HASIL PENELITIAN}

Hubungan Jumlah Pemberian Hijauan Dan Jumlah Pemberian Air Minum Terhadap Umur Pertama Beranak Sapi PO

Umur pertama beranak sapi PO di Desa Purwodadi Kecamatan Tanjung Sari adalah 3,36 \pm 0,50 tahun tergolong lebih lambat jika dibandingkan dengan umur pertama beranak pada sapi Bos Taurus (Simmental) yakni 28,16 $\pm 3,31$ bulan. Umur pertama kali beranak ditentukan oleh umur pertama kali ternak betina dikawinkan. (Handiwirawan dan Subandriyo, 2007).

Tabel 2. Regresi dan korelasi antar variabel

\begin{tabular}{ccccc}
\hline Umur Pertama Beranak & r & R-sq & R-eq & $\begin{array}{c}\text { Nilai Umur pertama } \\
\text { beranak }\end{array}$ \\
\hline $\begin{array}{c}\text { Jumlah pemberian } \\
\text { hijauan }\end{array}$ \\
$\begin{array}{c}\text { Jumlah pemberian air } \\
\text { minumb }^{b}\end{array}$ & $-0,419$ & $17,53 \%$ & $5,227-0,041$ & \\
\hline
\end{tabular}

Keterangan: superscript ' $\mathrm{b}$ ' artinya pengaruh variabel sangat nyata $(\mathrm{P}:<0,01)$ terhadap umur pertama beranak; r: korelasi; R-sq: R square (regresi); R-eq: R equivation (persamaan regresi).

Jumlah pemberian hijauan berpengaruh sangat nyata $(\mathrm{P}<0,01)$ terhadap nilai umur pertama beranak. Nilai $\mathrm{r}-0,419$ mengartikan tingkat keeratan jumlah pemberian hijauan dengan umur pertama beranak tergolong sedang. Nilai R-sq 17,53\% mengartikan jumlah pemberian hijauan berpengaruh terhadap umur pertama beranak sebanyak 17,53\% dan ada faktor lain sebanyak $82,47 \%$ yang dapat memengaruhi umur pertama beranak. Nilai R-eq $(-0,041)$ berasosiasi negatif mengartikan semakin banyak jumlah pemberian hijauan maka akan semakin cepat umur pertama beranak. Hal ini dikarenakan jumlah pakan yang diberikan berpengaruh terhadap kecukupan protein yang dapat berdampak pada timbulnya birahi lemah atau kuat, silent heat, dan kawin berulang (Prihatno et al, 2013).

Jumlah pemberian air minum berpengaruh sangat nyata $(\mathrm{P}<0,01)$ terhadap nilai umur pertama beranak. Nilai $\mathrm{r}-0,433$ mengartikan tingkat keeratan jumlah pemberian air minum terhadap umur pertama beranak tergolong sedang. Nilai R-sq 18,76\% mengartikan jumlah 
pemberian air minum berpengaruh terhadap umur pertama beranak sebanyak $18,76 \%$ dan ada faktor lain sebanyak $81,24 \%$ yang memengaruhi umur pertama beranak. Nilai R-eq $=(-0,016)$ berasosiasi negatif mengartikan semakin banyak jumlah pemberian air minum maka umur pertama beranak akan semakin cepat. Fungsi air untuk sapi adalah sebagai zat pelarut dan pengangkut zat makanan, membantu proses pencernaan, penyerapan dan pembuangan hasil metabolisme, memperlancar reaksi kimia dalam tubuh, pengatur suhu tubuh dan membantu kelancaran kerja syaraf panca indra (Febrianthoro et al, 2015).

\section{KESIMPULAN}

Umur pertama beranak sapi PO adalah 3,36 \pm 0,50. Jumlah pemberian hijauan dan jumlah pemberian air minum berpengaruh sangat signifikan serta berasosiasi negatif terhadap umur pertama beranak. Tingkat keeratan jumlah pemberian hijauan dan jumlah pemberian air minum terhadap umur pertama beranak tergolong sedang.

\section{DAFTAR PUSTAKA}

Febrianthoro, F., Hartono, M., \& Suharyati, S. (2015). Faktor-Faktor yang Memengaruhi Conception Rate pada Sapi Bali di Kabupaten Pringsewu. Jurnal Ilmiah Peternakan Terpadu, 3(4).

Foldager JK, Serjsen, Larsan JB. 1988. Feed intake and growth in the rearing period as well as the milk production in the first lactation in heifers feed ad libitum with barley, food sugar beets and long barley straw. J. Dairy Sci. 61: 173.

Handiwirawan E. dan Subandriyo., 2007. Potensi dan Keragaman Sumberdaya Genetik Sapi Bali.http://peternakan.litbang.dep tan.go.id/download/sapi /sapo 04-9 pdf.

https:// lampungprov.go.id/ detail-post/ tanjung-sari-di-jadikan-sentra-peternakan-sapi-dilampung (diakses pada 16 November 2020).

Pirlo, G., Miglior, F., \& Speroni, M. (2000). Effect of age at first calving on production traits and on difference between milk yield returns and rearing costs in Italian Holsteins. Journal of dairy science, 83(3), 603-608.

Prihatno, A. Kusumawati., N. W. K. Karja dan B. Sumiarto. 2013. Profil Biokimia Darah Pada Sapi Perah Yang Mengalami Kawin Berulang. J. Kedokteran Hewan. 7 (1) : 29-31.

Salisbury GW, Demarck NLV. 1961. Fisiologi Reproduksi dan Inseminasi Buatan pada Sapi . Djanuar R, penerjemah. Yogyakarta (ID): UGM press. Terjemahan dari: Physiology of Reproduction and Artificial Insemination of Cattle.

Somantri A, Sambas A. 2006. Aplikasi Statistika Dalam Penelitian. Bandung (ID): CV Pustaka Setia.

Steel RGD, Torrie JH. 1997. Prinsip dan Prosedur Statistika. Terjemahan: Sumantri B. Jakarta (ID): PT Gramedia Pustaka Utama.

Walpole, RE. 1992. Pengantar Statistika.Jakarta (ID): PT Gramedia. 